\title{
Climatological aspects of the extreme European rainfall of August 2002 and a trajectory method for estimating the associated evaporative source regions
}

\author{
P. James ${ }^{1}$, A. Stohl ${ }^{2}$, N. Spichtinger ${ }^{1}$, S. Eckhardt ${ }^{1}$, and C. Forster ${ }^{1}$ \\ ${ }^{1}$ Department of Ecology, Technical University of Munich, Germany \\ ${ }^{2}$ Cooperative Institute for Research in Environmental Sciences, NOAA Aeronomy Laboratory, University of Colorado, \\ Boulder, CO, USA
}

Received: 12 May 2004 - Revised: 9 November 2004 - Accepted: 10 November 2004 - Published: 18 November 2004

\begin{abstract}
During the first half of August 2002, a sequence of extreme precipitation episodes affected many regions of central and southern Europe, culminating in one of the most severe flooding events ever experienced along sections of the river Elbe and its tributaries. In this paper, the synoptic meteorological situation during the primary flooding event, 1113 August 2002, and its recent background is illustrated and discussed. Then, backward trajectory modelling of water vapour transport is employed to determine the sources and transport pathways of the moisture which rained out during the event. The Lagrangian trajectory model FLEXTRA is used together with high resolution operational meteorological analyses from the ECMWF to track a very large number of trajectories, initialized in a dense three-dimensional grid array over the extreme rainfall region. Specific humidity changes along each trajectory are mapped out to yield source-receptor relationships between evaporation and subsequent precipitation for the event. Regions of significant surface evaporation of moisture which later rained out were determined to be parts of the Aegean and Ligurian Seas during the initial stages of the event, while strong evaporation from eastern European land surfaces and from the Black Sea became dominant later on. The method also provides precipitation estimates based solely on specific humidity changes along Lagrangian airmass trajectories, which can be compared to ECMWF model forecast precipitation estimates.
\end{abstract}

\section{Introduction}

Early August 2002 will long be remembered for the exceptionally severe weather which descended on parts of central and southern Europe. Devastating flash floods occurred on the Russian Black Sea coast, killing more than 100 people, and in Majorca where $224 \mathrm{~mm}$ of rain fell in $3 \mathrm{~h}$. Violent hailstorms over parts of Italy and severe thunderstorms over

Correspondence to: P. James

(paul.m.james@metoffice.gov.uk)
Greece and eastern Spain resulted in further considerable damage. Especially intense downpours over north-eastern Austria on 6-7 August, where $48 \mathrm{~h}$ rainfall totals exceeded $150 \mathrm{~mm}$ in places, brought some of the worst flooding on record in the area.

Through this period, central and southern Europe was under a quasi-stationary trough in which individual convective systems were readily generated. Finally, a well-developed cyclone was generated over the Mediterranean. This subsequently moved north across the Alps, transporting immense volumes of precipitable water at a time of year when relatively high sea surface temperatures (SST) enhance evaporation and high air temperatures increase the potential amounts of moisture that the atmosphere can carry. More than 2 days of torrential rain across parts of eastern Germany and neighbouring regions resulted in disastrous flooding along tributaries of the Elbe and later the Elbe itself (Ulbrich et al., 2003a, b). The city centre of Dresden was inundated as the Elbe reached a historical record depth $940 \mathrm{~cm}$. This can be put into context by comparison with the meagre depth of barely $80 \mathrm{~cm}$ a year later, during the hot, drought summer of 2003. Even more extreme was the estimated peak flow rate of $4680 \mathrm{~m}^{3} \mathrm{~s}^{-1}$ compared to the long term August mean flow rate of $213 \mathrm{~m}^{3} \mathrm{~s}^{-1}$ and the very low mean value of $102 \mathrm{~m}^{3} \mathrm{~s}^{-1}$ in August 2003 (Saxony, 2002, 2003).

Other smaller towns in Saxony, lying along tributaries of the Elbe, suffered catastrophic flooding, destroying many buildings and sweeping several people to their deaths. A root cause of these tragic local events can certainly be found in the orographic enhancement of precipitation falling in the Erzgebirge mountains bordering Saxony and the Czech Republic. The station Zinnwald-Georgenfeld recorded $312 \mathrm{~mm}$ of rain in a standard $24 \mathrm{~h}$ period, breaking the all-time German national record, while the $48 \mathrm{~h}$ total there exceeded $400 \mathrm{~mm}$ (Rudolf and Rapp, 2003). 37 people died in Central Europe from this single flooding episode, bringing the total weather-related death toll across Europe since the start of August to 230. These events have brought home the dramatic impact that large-scale transport of water vapour can 

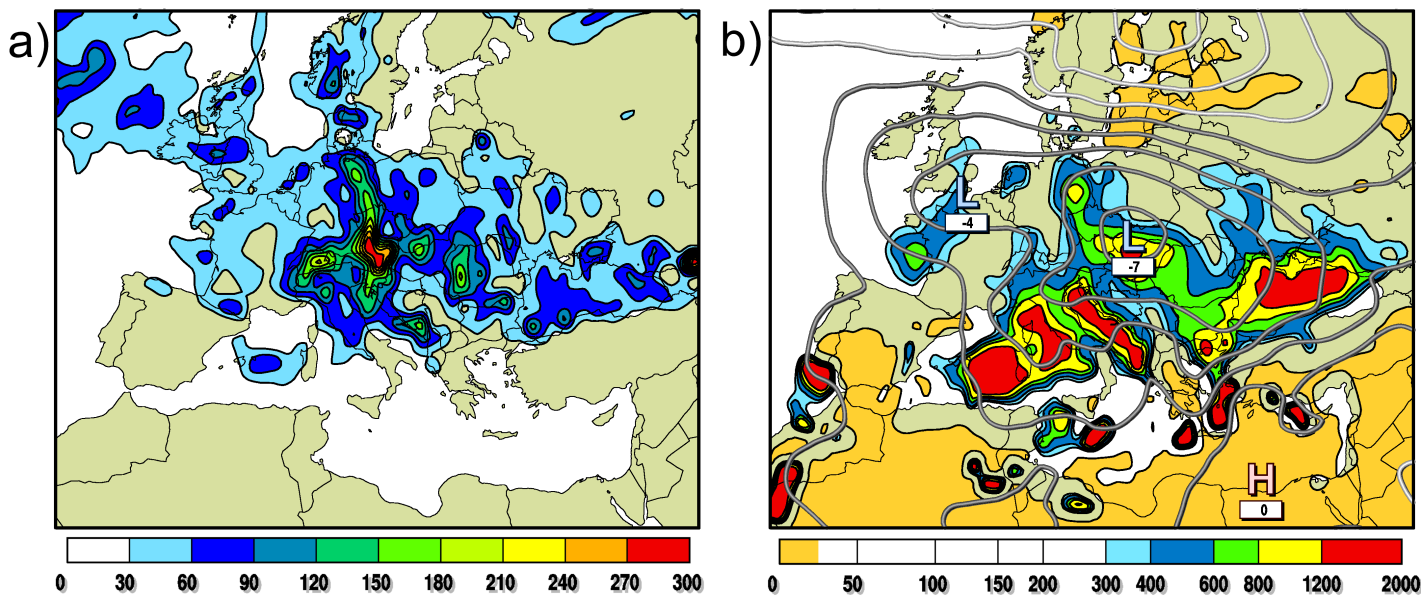

Fig. 1. (a) 14-day total precipitation (mm) starting 1 August 2002 at 00:00 UTC, based on operational ECMWF forecasts. Values less than $30 \mathrm{~mm}$ are not plotted. (b) Significant 14-day precipitation anomalies (\%) and mean sea-level pressure anomalies (contours) for the same period, based on ECMWF ERA-40 data relative to the climate means for the first half of August during a 30-year reference period, 1971-2000. Only those precipitation anomalies below $25 \%$ or above $300 \%$ of normal are plotted.

have, given critical meteorological conditions and abnormal levels of precipitable water.

Water vapour itself is the most important greenhouse gas in the atmosphere (e.g. Houghton et al., 2001) and strongly influences the climate system's sensitivity to changes in other greenhouse gas concentrations (Schneider et al., 1999). Water modifies the earth's radiation budget also through the formation of clouds, which lead to heating in some regions (e.g. close to the poles) (Garrett et al., 2002) or for some cloud types (e.g. cirrus) and cooling in most other regions and for low clouds. Evapotranspiration and precipitation regulate the regional supply with water, and extreme conditions (drought or flooding) severely impact on both natural ecosystems and human society. Furthermore, water vapour serves to cleanse the atmosphere of pollutants and aerosols, and the water vapour budget itself is influenced by anthropogenic pollution. Thus, the water cycle is perhaps the most important single element in the climate system with significant links to several biogeochemical cycles. Nevertheless, the water cycle is still poorly understood, while even key parameters such as the global evapotranspiration and precipitation distribution are not known with sufficient accuracy. Even less well known are the typical pathways of water in the atmosphere (Newell et al., 1992) and particularly the source-receptor relationships between evapotranspiration in one area and precipitation elsewhere.

Precipitation falling over a given area, whether resulting from convective activity, frontal systems or orographicallyinduced uplift, is a collection of water molecules amassed from potentially many sources and at potentially a wide range of times in the recent past. Some of the water may come from evaporation of falling hydrometeors or may be supplied from surface evaporation or biomass transpiration in the immediate vicinity, for example during the development of a localised summer thunderstorm. Some water may be transported from more distant land surfaces or may have evaporated from ocean surfaces, perhaps thousands of kilometres away.

The catastrophic flooding events in August 2002 have shown that it is vital to establish concrete links between evaporation fluxes and subsequent rainfall, with respect to influencing factors such as surface moisture and SSTs. One possibility to determine the source regions of precipitated water is isotopic analysis of precipitation samples. The hydrogen and oxygen isotope ratios can be measured and compared with estimates derived from an empirical relationship with air humidity values over the supposed source regions and based on meteorological data. Recent applications of this method include Yamanaka et al. (2002) for rainfall over Japan and Weyhenmeyer et al. (2002) who found that rainfall over Oman could be separated into events with a Mediterranean source and events with an Indian Ocean source. However, this approach has fundamental limitations because it requires detailed analyses of rain samples.

Another approach, for which rain sample analysis is unnecessary, is to employ a general circulation model (GCM) to simulate precipitation events. Keil et al. (1999) re-ran a high-resolution limited-area forecast model to simulate the transport of moisture during another recent extreme rainfall event which affected southern Poland and the Czech Republic in July 1997, resulting in severe flooding along the River Oder. Such model integrations can also be compared with or without modifications to the model's hydrological equations. Thus, removing the surface source of water vapour in a simulation by reducing the surface moisture flux, Bosilovich and Sun (1999) were able to show that up to $20 \%$ of the rainfall responsible for the severe flooding along the Mississippi basin in the summer of 1993 was due to locally evaporated (recycled) water. Using a different approach to modelling the 1993 flood event, Viterbo and Betts (1999) examined how changing the input soil water content, derived from ECMWF analyses, influenced the forecast precipitation levels. When 
Table 1. 6-hourly precipitation totals $(\mathrm{mm})$ at selected central European stations, ending at the respective given times, derived from standard Synop-Reports. A dash indicates that no precipitation fell during the given period, whereas 0 indicates that precipitation was recorded, but did not exceed $0.4 \mathrm{~mm}$.

\begin{tabular}{|c|c|c|c|c|c|c|c|c|c|c|c|c|c|c|c|}
\hline \multirow{2}{*}{$\begin{array}{l}\text { Date: } \\
\text { Hour: }\end{array}$} & \multicolumn{4}{|c|}{11 August } & \multicolumn{4}{|c|}{12 August } & \multicolumn{4}{|c|}{13 August } & \multicolumn{2}{|c|}{14 August } & \multirow[b]{2}{*}{ Total } \\
\hline & 06 & 12 & 18 & 00 & 06 & 12 & 18 & 00 & 06 & 12 & 18 & 00 & 06 & 12 & \\
\hline Station: & & & & & & & & & & & & & & & \\
\hline$\overline{\text { Brocken }}$ & 1 & 0 & 0 & 52 & 49 & 9 & 3 & 1 & 1 & 1 & - & 0 & 0 & 0 & 117 \\
\hline Dresden & - & - & 0 & 0 & 11 & 64 & 52 & 22 & 21 & 7 & 6 & 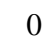 & 0 & 0 & 183 \\
\hline Fichtelberg & 2 & 0 & 6 & 26 & 28 & 40 & 32 & 44 & 17 & 1 & 1 & 0 & 1 & 3 & 201 \\
\hline Goerlitz & - & - & 0 & 0 & 5 & 6 & 2 & 0 & 10 & 25 & 32 & 16 & 1 & - & 97 \\
\hline Linz & - & 3 & 8 & 5 & 45 & 29 & 18 & 17 & 8 & - & - & - & - & - & 133 \\
\hline Potsdam & 0 & - & - & 0 & 7 & 21 & 43 & 16 & 4 & 14 & 2 & - & - & - & 107 \\
\hline Prague & - & - & 0 & 4 & 17 & 13 & 14 & 12 & 11 & 0 & 5 & 2 & - & - & 78 \\
\hline Salzburg & 1 & 6 & 3 & 27 & 43 & 15 & 3 & 1 & 1 & - & - & - & - & - & 100 \\
\hline Vienna & - & 0 & 51 & 2 & 1 & 5 & 13 & 20 & 10 & 21 & 9 & 2 & 2 & - & 136 \\
\hline Wittenberg & 0 & 0 & 4 & 0 & 5 & 23 & 12 & 2 & 1 & 0 & 1 & 0 & 0 & 0 & 48 \\
\hline Zinnwald & - & 0 & 7 & 2 & 59 & 99 & 95 & 69 & 50 & 23 & 3 & 1 & 0 & 1 & 409 \\
\hline
\end{tabular}

soil water fields based on levels during the severe drought of 1988 were used, a reduction of ensemble forecast precipitation of around $40 \%$ was noted. In a similar study on the relationship between soil moisture and precipitation, Schär et al. (1999) performed month-long climate model simulations to demonstrate that summer rainfall levels over Europe are strongly influenced by soil moisture content via associated evapo-transpiration, although the nature of the feedbacks involved in the local water budgets is complex.

A natural extension of this method is to incorporate constituent tracers of regional water vapour sources into a climate model simulation. Using such an approach, Bosilovich and Schubert (2002) showed that locally evaporated water accounts for a much higher proportion of rainfall over the continental US than it does over India, where most rainfall has an oceanic source. Furthermore, Bosilovich (2002) employed such a tracer simulation to estimate the vertical distributions of local and remote sources of water for precipitation.

The Lagrangian analogue to such Eulerian tracer methods is the trajectory approach (Stohl, 1998). Here relying entirely on analysis data, backward air flow trajectories allow an explicit evaluation of likely source regions for the water vapour involved in precipitation (Wernli and Davies, 1997). For example, Massacand et al. (1998) computed back-trajectories for specific cases of exceptional rainfall on the southern side of the Alps and found that the associated airmasses typically moved slowly northwards at low altitude, gaining significant moisture from the sea surface before ascending rapidly, saturating and raining out over the mountains. Dirmeyer and Brubaker (1999) calculated quasi-isentropic back-trajectories using NCEP re-analyses, estimating that up to $40 \%$ of the precipitation originated as evaporation from the same basin. Extending the findings of that case-study, Brubaker et al. (2001) deployed their back-trajectory algorithm to produce a 36 year climatology of moisture sources for the Mississippi basin, showing that $32 \%$ of the precipitation was sourced locally, while $20 \%$ was evaporated out of the Gulf of Mexico and the Caribbean. Meanwhile, Reale et al. (2001) applied the same algorithm to estimate the evaporative sources of moisture involved in severe flooding episodes in the western Mediterranean in early October 1998, showing that additional moisture input from sub-tropical Atlantic hurricanes played an important role. Using instead ECMWF re-analyses, Reijmer et al. (2002) computed fiveday backward 3D trajectories to define potential moisture sources of snow falling at five Antarctic deep drilling locations, making a distinction between cases with and without snowfall at the point of arrival, based on model precipitation estimates. Trajectories have recently also been used to determine the pathways of water vapour from the troposphere into the stratosphere (Jackson et al., 1998).

Such experiments have demonstrated the potential of Lagrangian techniques for determining water vapour sources. In this paper, a novel Lagrangian method employing a large number of backward trajectories will be applied to the flooding episode of 11-13 August 2002 to determine the sources and transport pathways of the moisture which rained out during the event. The Lagrangian trajectory model FLEXTRA is used together with high resolution operational ECMWF meteorological analyses to track a very large number of trajectories, initialized in a dense 3D grid array over the extreme rainfall region. Specific humidity changes along each trajectory, also based on operational ECMWF analyses, are mapped out to yield source-receptor relationships between evaporation and subsequent precipitation for the event.

The synoptic meteorological situation during the event and its recent background is illustrated and discussed in Sect. 2. The results of the trajectory analysis, in which the regions of significant surface evaporation of moisture which later rained out are determined, are discussed in Sect. 3 alongside a discussion of precipitation estimates based solely on specific humidity changes along Lagrangian airmass trajectories, provided by the method, which are compared to ECMWF model forecast precipitation estimates. 


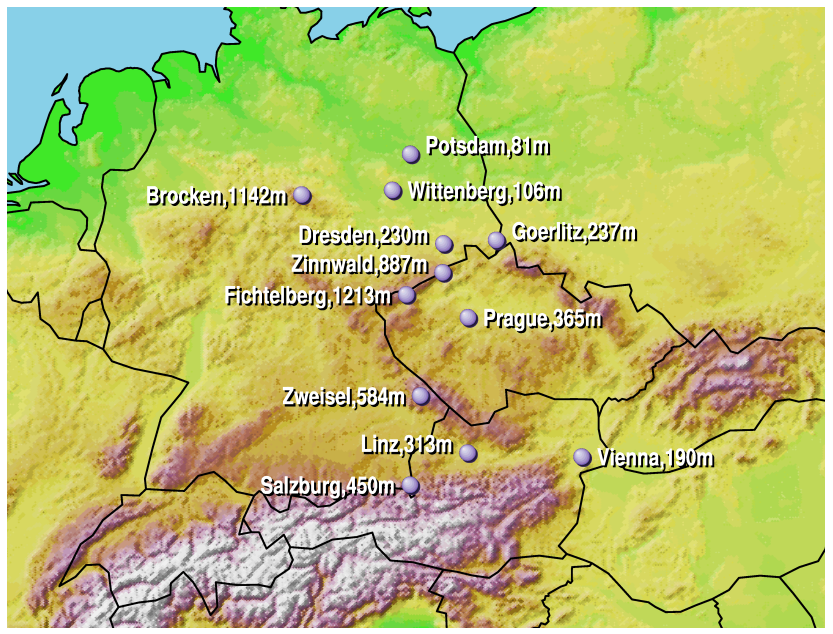

Fig. 2. Map showing locations and altitudes (above mean sea level) of the central European stations mentioned in the text and listed in Table 1.

\section{The meteorology of the flooding event, 11-13 August 2002}

For the first two weeks of August 2002, unusually persistent quasi-stationary mid-tropospheric troughs were located over central and southern Europe. Even over parts of the Mediterranean, where dry and sunny conditions normally persist at that time of year, active convective systems generated within this trough-structure led to exceptionally heavy rainstorms, while over the central European mainland, slowmoving frontal bands brought record rainfall totals in places.

Figure 1a shows an estimate of the total precipitation falling during the first 14 days of August, based on $\mathrm{T}+3 \mathrm{~h}$ and $\mathrm{T}+6 \mathrm{~h}$ operational ECMWF forecasts. Although smallscale local variations, which can be very significant in convective systems or in mountainous regions, are smoothed out in this dataset and systematic errors cannot be ruled out, it is clear that unusually high rainfall totals occurred, notably over Austria and neighbouring regions, where up to $300 \mathrm{~mm}$ fell.

In order to illustrate the extreme nature of these totals in the context of earlier records, the new ERA40 reanalysis dataset from ECMWF is employed to estimate rainfall anomaly fields. The ERA40 dataset, which starts in September 1957, was extended to include August 2002 to aid studies of the flooding events. ERA40 rainfall estimates are significantly lower than equivalent operational model estimates, presumably due to the lower intrinsic model resolution, and cannot be used for a direct comparison with the operational data. However, a qualitative comparison of the August 2002 events with the ERA40 climatology is useful. Here, 30-year monthly mean precipitation totals have been constructed for the period 1971-2000 and are fitted with smooth interpolating curves to provide an estimate of the precipitation climatology for the exact period of 1-14 August. Figure $1 \mathrm{~b}$ shows that a large area of Europe had more

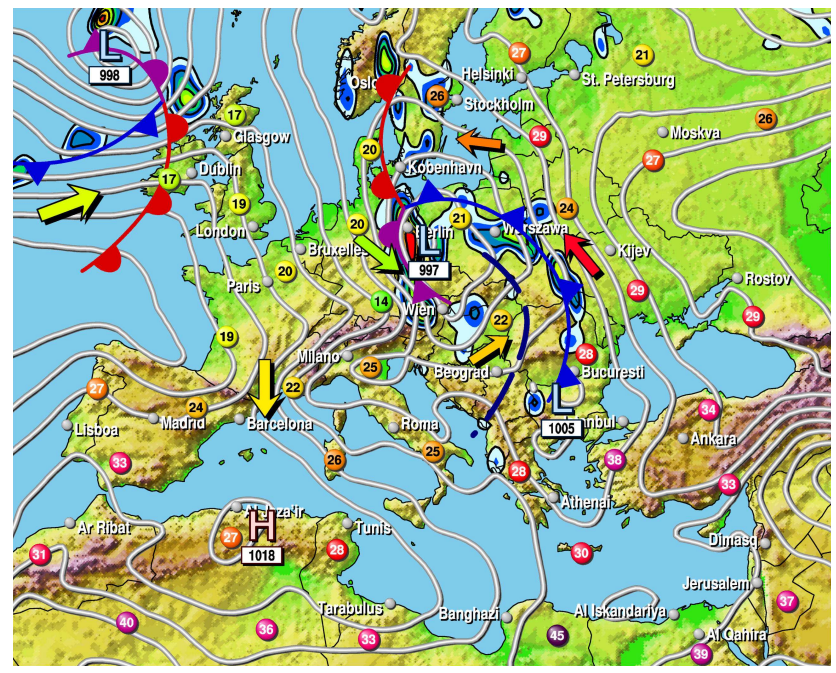

Fig. 3. Surface analysis at $12: 00$ UTC, 12 August 2002, based on ERA40 data, showing mean sea-level pressure contours, interval $2.5 \mathrm{hPa}$, indicating pressure centres and significant fronts, with disks showing the temperature in $\operatorname{deg} \mathrm{C}$ at $2 \mathrm{~m}$ above the surface at selected locations and qualitative arrows indicating surface wind direction. The coloured contours show regions where the instantaneous precipitation rate exceeds $0.5 \mathrm{~mm} / \mathrm{h}$. Major contour interval (solid lines) is $1 \mathrm{~mm} / \mathrm{h}$; maximum level (red) is $5 \mathrm{~mm} / \mathrm{h}$.

than 3 times the climatological average rainfall. In the regions of central Europe most affected by the flooding events, more than 10 times the normal rainfall fell, while in parts of southern and south-eastern Europe, up to or even more than 20 times the normal amounts fell. The equivalent anomaly field of mean sea-level pressure for this period, illustrates the mean cyclonic anomaly of $7 \mathrm{hPa}$ centred over Hungary, while high pressure is located over Scandinavia, where the period was unusually dry.

For the remainder of this paper, the meteorological situation has been illustrated primarily with ERA40 data. This data is especially useful when forming anomaly fields compared to a reference period. However, due to the limitations of ERA40 with regards to precipitation and evaporation estimates, operational ECMWF data has been used for illustrations of these fields and for the experiments described in Sect. 3. The operational model is based on a higher spatial resolution than the ERA40 model. Thus, ERA40 tends to underestimate precipitation and evaporation totals, relative to operational model estimates for the same events.

Focussing now on the major flooding event of 11-13 August, Table 1 lists a set of observed 6-hourly rainfall totals at various selected stations in central Europe. The locations and altitudes of these stations is shown in Fig. 2 for reference. While the greatest totals were recorded in hilly regions (Fichtelberg, Zinnwald), it can be seen that a large area was affected by the heavy rainfall, stretching from near Berlin (Potsdam) in the north, to Prague and Vienna in the east and beyond Salzburg and the Alps to the south. Comparing these values (and observed totals for the whole period since $1 \mathrm{Au}-$ 
Table 2. List of the 10 greatest area-mean precipitation totals falling over any one-million square kilometre area centred within the domain $43^{\circ}-57^{\circ} \mathrm{N}, 3^{\circ}-27^{\circ} \mathrm{E}$, over time intervals of (left-hand side) $96 \mathrm{~h}$ and (right-hand side) $168 \mathrm{~h}$, based on ECMWF ERA-40 T+3 h and T+6 h precipitation forecasts, January 1958 to August 2002.

\begin{tabular}{|c|c|c|c|c|c|c|}
\hline & Start time $(96 \mathrm{~h})$ & Location centre & Mean prec. $(\mathrm{mm})$ & Start time $(168 \mathrm{~h})$ & Location centre & Mean prec. $(\mathrm{mm})$ \\
\hline 1 & 3 Sept. $1992,18 \mathrm{~h}$ & $51^{\circ} \mathrm{N}, 24^{\circ} \mathrm{E}$ & 40.0 & 6 Aug. 2002, 06 h & $48^{\circ} \mathrm{N}, 14^{\circ} \mathrm{E}$ & 57.6 \\
\hline 2 & 6 Aug. $1978,09 \mathrm{~h}$ & $52^{\circ} \mathrm{N}, 15^{\circ} \mathrm{E}$ & 39.4 & 7 Oct. $1980,18 \mathrm{~h}$ & $43^{\circ} \mathrm{N}, 17^{\circ} \mathrm{E}$ & 56.0 \\
\hline 3 & 9 Aug. 2002, $06 \mathrm{~h}$ & $45^{\circ} \mathrm{N}, 13^{\circ} \mathrm{E}$ & 39.4 & 13 July $2002,00 \mathrm{~h}$ & $44^{\circ} \mathrm{N}, 07^{\circ} \mathrm{E}$ & 55.2 \\
\hline 4 & 27 Dec. $1978,18 \mathrm{~h}$ & $49^{\circ} \mathrm{N}, 06^{\circ} \mathrm{E}$ & 39.2 & 11 Nov. $1972,21 \mathrm{~h}$ & $48^{\circ} \mathrm{N}, 07^{\circ} \mathrm{E}$ & 55.0 \\
\hline 5 & 19 Oct. $1974,12 \mathrm{~h}$ & $45^{\circ} \mathrm{N}, 14^{\circ} \mathrm{E}$ & 38.5 & 21 Sept. 1973,12 h & $46^{\circ} \mathrm{N}, 12^{\circ} \mathrm{E}$ & 54.6 \\
\hline 6 & 18 Aug. $1972,00 \mathrm{~h}$ & $43^{\circ} \mathrm{N}, 14^{\circ} \mathrm{E}$ & 38.4 & 5 Sept. 2001,09 h & $46^{\circ} \mathrm{N}, 25^{\circ} \mathrm{E}$ & 54.0 \\
\hline 7 & 8 Oct. $1980,00 \mathrm{~h}$ & $46^{\circ} \mathrm{N}, 14^{\circ} \mathrm{E}$ & 38.2 & 24 Oct. $1998,15 \mathrm{~h}$ & $54^{\circ} \mathrm{N}, 08^{\circ} \mathrm{E}$ & 53.1 \\
\hline 8 & 18 Nov. $1971,06 \mathrm{~h}$ & $47^{\circ} \mathrm{N}, 06^{\circ} \mathrm{E}$ & 37.7 & 16 Aug. 1972, 09 h & $50^{\circ} \mathrm{N}, 21^{\circ} \mathrm{E}$ & 52.6 \\
\hline 9 & 17 July 1997,21 h & $51^{\circ} \mathrm{N}, 17^{\circ} \mathrm{E}$ & 37.7 & 17 Dec. $1991,15 \mathrm{~h}$ & $47^{\circ} \mathrm{N}, 06^{\circ} \mathrm{E}$ & 52.1 \\
\hline 10 & 21 Sept. 1973,15 h & $46^{\circ} \mathrm{N}, 12^{\circ} \mathrm{E}$ & 37.6 & 16 Oct. $1974,06 \mathrm{~h}$ & $45^{\circ} \mathrm{N}, 14^{\circ} \mathrm{E}$ & 51.5 \\
\hline
\end{tabular}

gust given in Ulbrich et al., 2003a) with operational ECMWF estimates, the latter has captured the spatial distribution and mean magnitudes of the precipitation very well, although local small-scale variations and orographic enhancements, such as the sharp gradients across the Erzgebirge between Dresden and Prague, have not been resolved in the ECMWF data (Fig. 1a), as is to be expected.

To assess how extreme this event was in terms of areamean rainfall compared to other events in recent decades, a further calculation utilizing ERA40 can be carried out. Here, area-mean precipitation totals, covering all possible rectangular one million square kilometre regions of Europe have been calculated for all possible $96 \mathrm{~h}$ and $168 \mathrm{~h}$ periods, respectively, over the ERA40 period. The 10 greatest such events in each case are presented in Table 2. For the $96 \mathrm{~h}$ time window, the August 2002 event produced the third highest area-mean rainfall total. When a longer time window of $168 \mathrm{~h}$ is used, hence allowing the 6-7 August flooding event in Austria to be added to the later event, the August 2002 case becomes the greatest of all during the last 44 years. It is interesting to note that all of the respective greatest rainfall events listed here occurred during the second half of the year, when SSTs are relatively high and synoptic systems become progressively more active as air temperatures drop at high latitudes.

The surface synoptic situation at the height of the extreme rainfall over eastern Germany is illustrated for 12:00 UTC on 12 August in Fig. 3. A relatively intense (for August) surface low is centred over the border of Saxony with Poland. This low had been centred over southern England on 9 August, had moved with a less compact centre to southern France by 10 August and had re-intensified over northern Italy on 11 August before moving north. Very warm air is being advected north and westwards over eastern Europe towards Scandinavia. A strong surface pressure gradient on the low's western flank is resulting in very strong, cool north-westerly winds at low levels. At the quasi-stationary front stretching north-south across eastern Germany, these cool north- westerlies are undercutting a buoyant, warm and very moist airmass moving in from the east. The convergence of these airmasses here is leading to heavy persistent rainfall, which is falling at a rate of more than $5 \mathrm{~mm} / \mathrm{h}$, according to operational ECMWF estimates. As the low-level north-westerly flow is forced to rise as it meets the Erzgebirge range, the resulting local orographic enhancement led to exceptionally high observed rainfall rates, averaging around $16 \mathrm{~mm} / \mathrm{h}$ at Zinnwald for several hours. At the Zinnwald station, the rainfall rate showed exceptional peaks of over $50 \mathrm{~mm} / \mathrm{h}$ at 05:00 UTC and again at 10:00 UTC on 12 August (Ulbrich et al., 2003a).

The development of the mid-tropospheric trough associated with the flooding event is illustrated in Fig. 4. The trough, which follows a similar path to the surface cyclone beneath it, causes an anomaly dipole of lower tropospheric temperatures to be generated. On the $850 \mathrm{hPa}$ surface, very cold air is advected into the western Mediterranean, while very warm air is advected out of the Sahara ahead of it. The trough is an exceptionally intense feature for the time of year. The daily mean $500 \mathrm{hPa}$ geopotential height anomaly reaches about -26 dam above Corsica on 11 August. This exceeds the extreme minimum anomaly of -22 dam at this location in August during the thirty year period, 1971-2000, according to ERA 40 data, and is about 4.5 standard deviations from the climate mean. The minimum daily mean $850 \mathrm{hPa}$ temperature anomaly on 11 August is about $-10.5 \mathrm{~K}$ near the northern coast of Algeria, which is about 2.6 standard deviations below the climate mean and is close to the 1971-2000 extreme August anomaly value of about $-12 \mathrm{~K}$ here. Similarly, the maximum $850 \mathrm{hPa}$ temperature anomaly of $+11 \mathrm{~K}$, some 3.5 standard deviations above the climate mean, is reached over north-western Turkey on 12 August and this actually exceeds the 1971-2000 extreme August anomaly value of about $+10 \mathrm{~K}$ here. Further north, it is interesting to note that the frontal zone of heavy rainfall on 12 August over eastern Germany has a light easterly flow in the mid-troposphere and a warm anomaly at $850 \mathrm{hPa}$ of between +2 and $+4 \mathrm{~K}$. 
a)

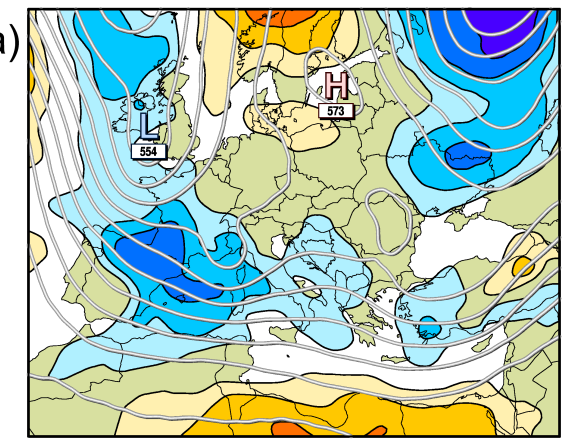

c)

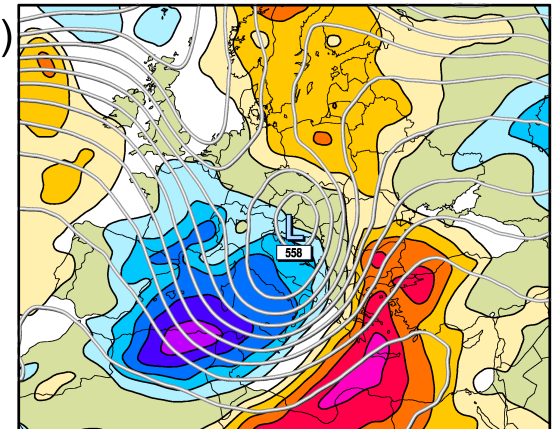

b)

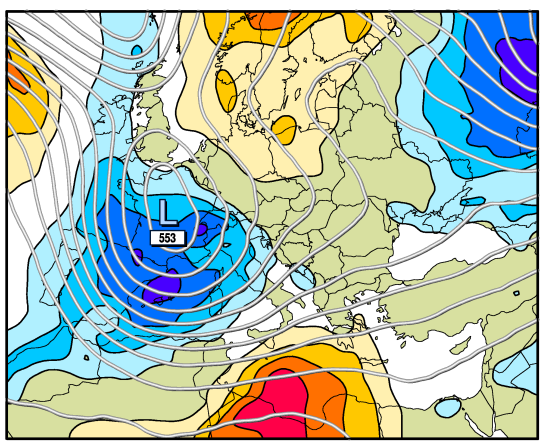

d)

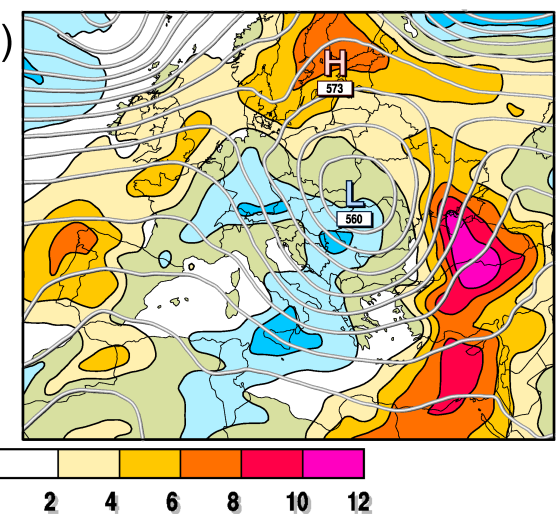

Fig. 4. Geopotential contours at $500 \mathrm{hPa}$, interval $4 \mathrm{dam}$, and anomalies of temperature at $850 \mathrm{hPa}$ based on ERA 40 analyses and relative to corresponding 30-year climate means for August, 1971-2000, for (a) 9 August at 00:00 UTC, (b) 10 August at 12:00 UTC, (c) 12 August at 00:00 UTC and (d) 13 August at 12:00 UTC.

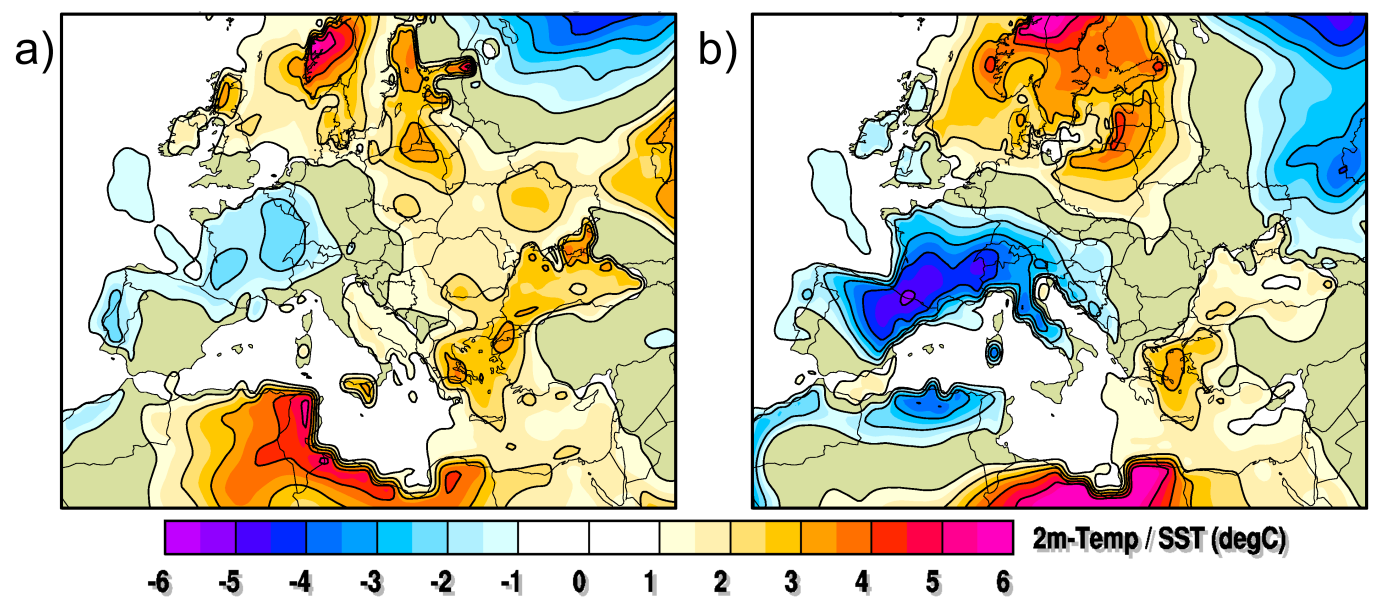

Fig. 5. 5-day mean anomalies of $2 \mathrm{~m}$-temperature (over land) and sea-surface-temperatures (over water), based on ERA40 analyses relative to corresponding 30-year climate means for the equivalent period in August, 1971-2000, for (a) 3-7 August and (b) 8-12 August 2002.

The cold-in-the-west and warm-in-the-east pattern above was a general feature of the first half of August, as can be expected given the mean surface pressure pattern (Fig. 1b). 5day mean anomalies of both $2 \mathrm{~m}$-temperature (over land) and sea-surface temperatures (where the respective grid-point is over sea), based on ERA40 analyses, are shown in Fig. 5 for the consecutive periods, 3-7 and 8-12 August. Over land, the cold conditions over Western Europe intensify later on, while the warm pole over the east becomes concentrated on
Scandinavia. SSTs appear to be near normal over the western Mediterranean, but are significantly above normal over the Aegean Sea and especially over the Black Sea, where SST anomalies reach $+4 \mathrm{~K}$ over the Azovsky Sea in the north. The combination of very high recent rainfall totals over the adjacent land regions and Eastern Europe in general with positive temperature anomalies gives a first indication that local surface evaporation levels were potentially high at this time. It should also be noted that the third highest $168 \mathrm{~h}$ area-mean 
a)

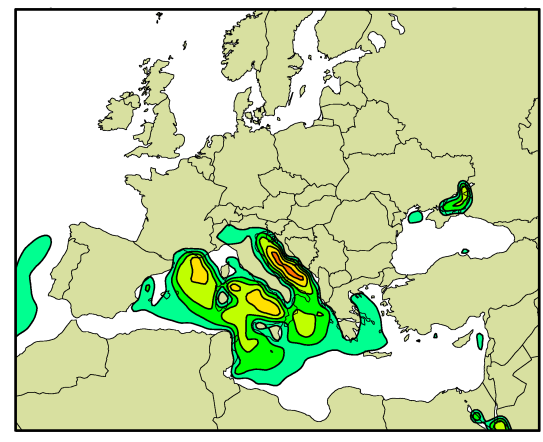

c)

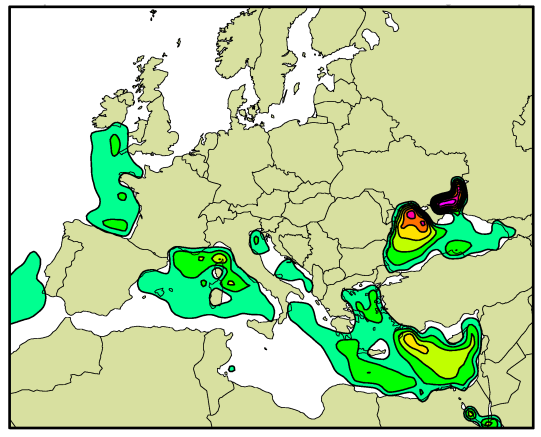

b)

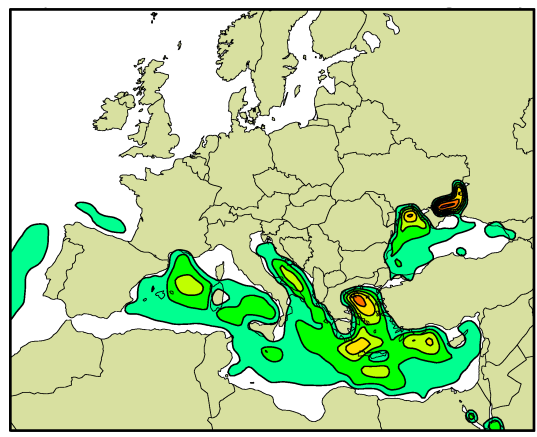

d)

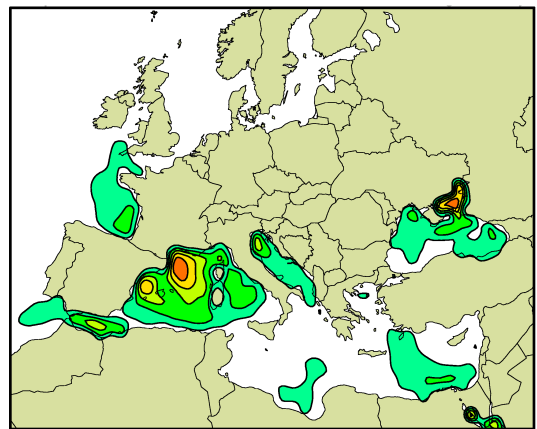

e)

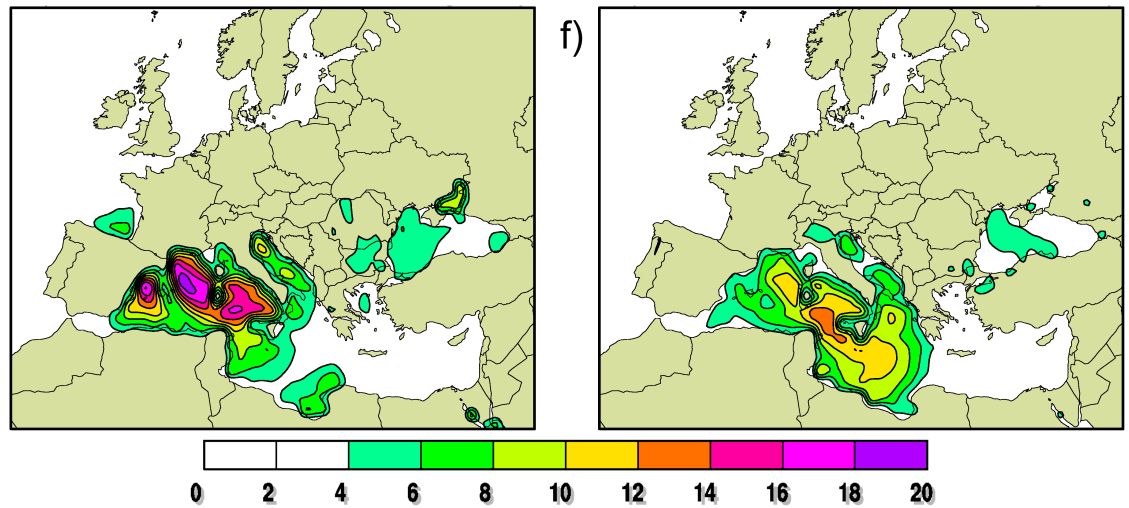

Fig. 6. Significant total daily surface evaporation (mm), based on operational ECMWF forecasts, for (a) 7 August, (b) 8 August, (c) 9 August, (d) 10 August, (e) 11 August and (f) 12 August 2002. Evaporation totals of less than $4 \mathrm{~mm} /$ day are not shown.

rainfall event during the last 44 years (Table 2) occurred just 4 weeks earlier in mid-July 2002, broadly centred on the French Alps. This event is also likely to have contributed a significant increase in European surface and soil moisture levels over the following weeks.

ECMWF operational forecast model estimates of significant daily total surface evaporation from 7-12 August are shown in Fig. 6. Areas of strongly enhanced evaporation are seen over the Mediterranean and Black Sea. When examining sequences of the 3-hourly accumulated evaporation fields (not shown), it can be seen that these are related to successive episodes of high evaporation, which move quickly from west to east. Such events are typically associated with regions of strong surface winds. In particular, the development of the strong trough on 10-12 August led to exceptionally high evaporation totals of up to $20 \mathrm{~mm} \mathrm{day}^{-1}$ in the western Mediterranean. The ERA40 estimate of this evaporation maximum is $14.6 \mathrm{~mm}_{\text {day }^{-1}}$. This can be compared to ERA40 climate mean values of around $2.9 \mathrm{~mm} \mathrm{day}^{-1}$ for August in this region. Indeed, the mean has been exceeded by almost 4 standard deviations in this case. Evaporation over land is typically smaller, with a strong diurnal component. Nevertheless, values exceeding $4 \mathrm{~mm} \mathrm{day}^{-1}$ are indicated over Romania and Bulgaria on 11 August.

The impact of this surface evaporation on the specific humidity field in the lower troposphere is indicated in Fig. 7. A swathe of increasingly very moist air is advected from across southern Italy into eastern Europe on 11 and 12 August, where the air is carrying up to $9 \mathrm{~g} \mathrm{~kg}^{-1}$ of water vapour. A further tongue of moist air stretches westwards over eastern Germany. In the frontal rain band itself, the air (at $700 \mathrm{hPa}$ ) holds up to $7 \mathrm{~g} \mathrm{~kg}^{-1}$ of water vapour, noting that here much of the available moisture is raining out at this time. 
a)

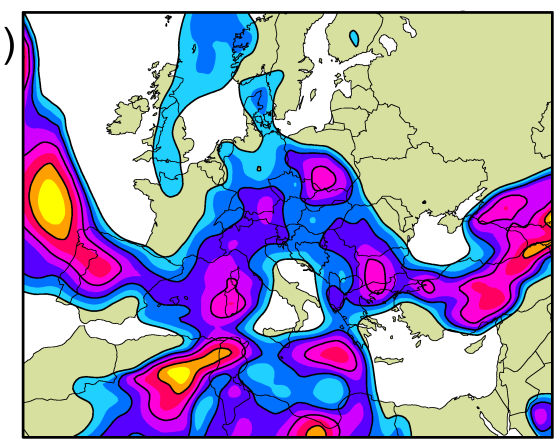

c)

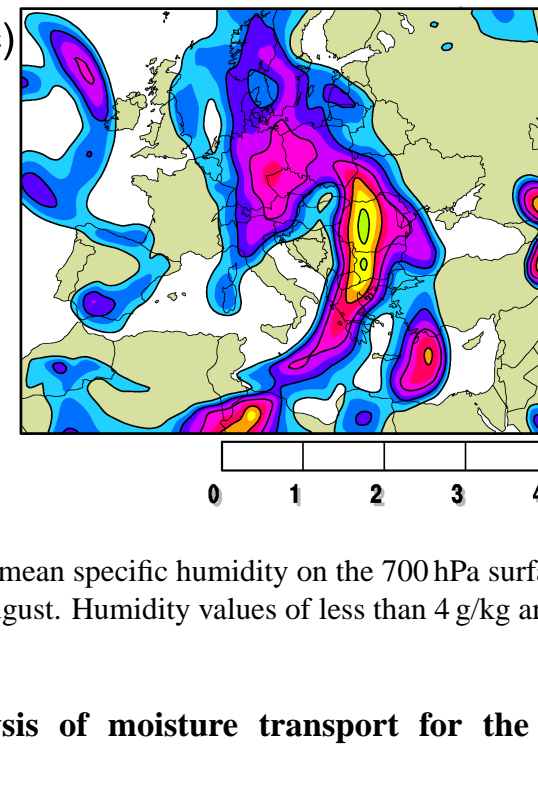

b)

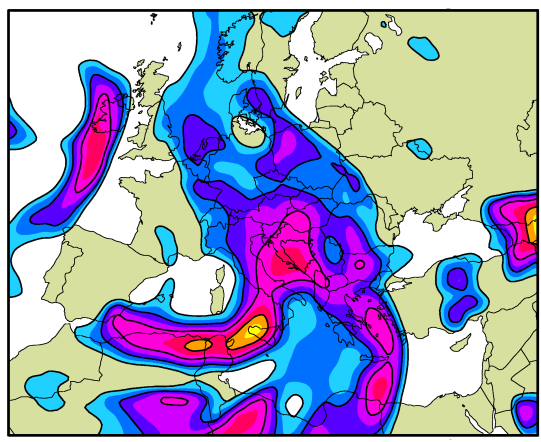

d)

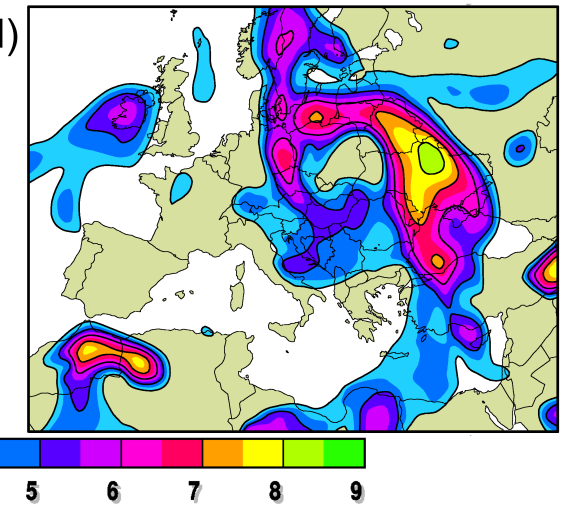

Fig. 7. Significant daily mean specific humidity on the $700 \mathrm{hPa}$ surface (g/kg), based on ERA40 analyses, for (a) 10 August, (b) 11 August, (c) 12 August, (d) 13 August. Humidity values of less than $4 \mathrm{~g} / \mathrm{kg}$ are not shown.

\section{Trajectory analysis of moisture transport for the flooding event}

The severe flooding event described above raises the question of how water vapour transport led to such extreme rainfall totals. Furthermore, if the primary surface evaporative sources of the water involved can be determined, can links be established to local anomalies in SST or soil moisture, or were the meteorological conditions alone sufficient to produce the extreme rainfall? Given the potential of trajectory methods for tracing airmass movements, the flooding event has been analysed in detail with the Lagrangian trajectory model, FLEXTRA, and with high resolution meteorological analysis and forecast fields from ECMWF.

FLEXTRA (http://www.forst.tu-muenchen.de/ext/lst/ meteo/stohl/flextra.html) is a Lagrangian model for calculating $3 \mathrm{D}$ trajectories, either forwards or backwards in time, based on high-density meteorological data with several user options to change trajectory types and initial configuration. FLEXTRA has been used to make the first detections of intercontinental transport of ozone (Stohl and Trickl, 1999) and of Canadian forest fire emissions over Europe (Forster et al., 2001), and was used for the first global airstream climatology (Stohl, 2001) and a 15-year climatology of warm conveyor belts (Eckhardt et al., 2004).

To illustrate at first some of the typical paths taken by air parcels involved in the extreme precipitation, individual backward trajectories have been calculated, ending at different times during heavy rainfall in vertical columns over a number of observing stations. The trajectory calculations are based on meteorological fields derived from 6-hourly operational ECMWF analyses, supplemented by $3 \mathrm{~h}$ forecasts, on a $0.5^{\circ} \times 0.5^{\circ}$ horizontal grid over the European and eastern Atlantic areas, nested within $1^{\circ} \times{ }^{1} \circ$ global fields, with 60 vertical levels, thus providing an accurate assessment of the $3 \mathrm{D}$ wind fields during the event. The ECMWF fields also provide fully $3 \mathrm{D}$ specific humidity fields, important for assessing moisture transport.

In Fig. 8, trajectories ending over Zinnwald, where the highest rainfall total was recorded, are shown. Changes in specific humidity along a Lagrangian trajectory must be due to either entrainment of moisture through mixing with surrounding air parcels, to local evaporation (increasing the specific humidity) or to condensation and possibly subsequent rainfall removing water by gravity (decreasing the specific humidity). Since the trajectories ending over Zinnwald are ending in a region of heavy rainfall, it can be expected that some of them will exhibit a significant loss of specific humidity during the last time step of their existence. Hence, in Fig. 8, the trajectories are coloured according to the specific humidity change during the last $90 \mathrm{~min}$ before arrival at their ending point. At 06:00 UTC on 12 August, during the early stages of the heaviest rainfall, the airmasses which are most strongly raining out arrived between 2 and $4 \mathrm{~km}$ above Zinnwald. Their trajectories traversed the western Mediterranean and the southern Adriatic sea at low levels, before forming a compact curve northwards across Serbia, Hungary and Slovakia, still at low levels, finally arriving from the east 

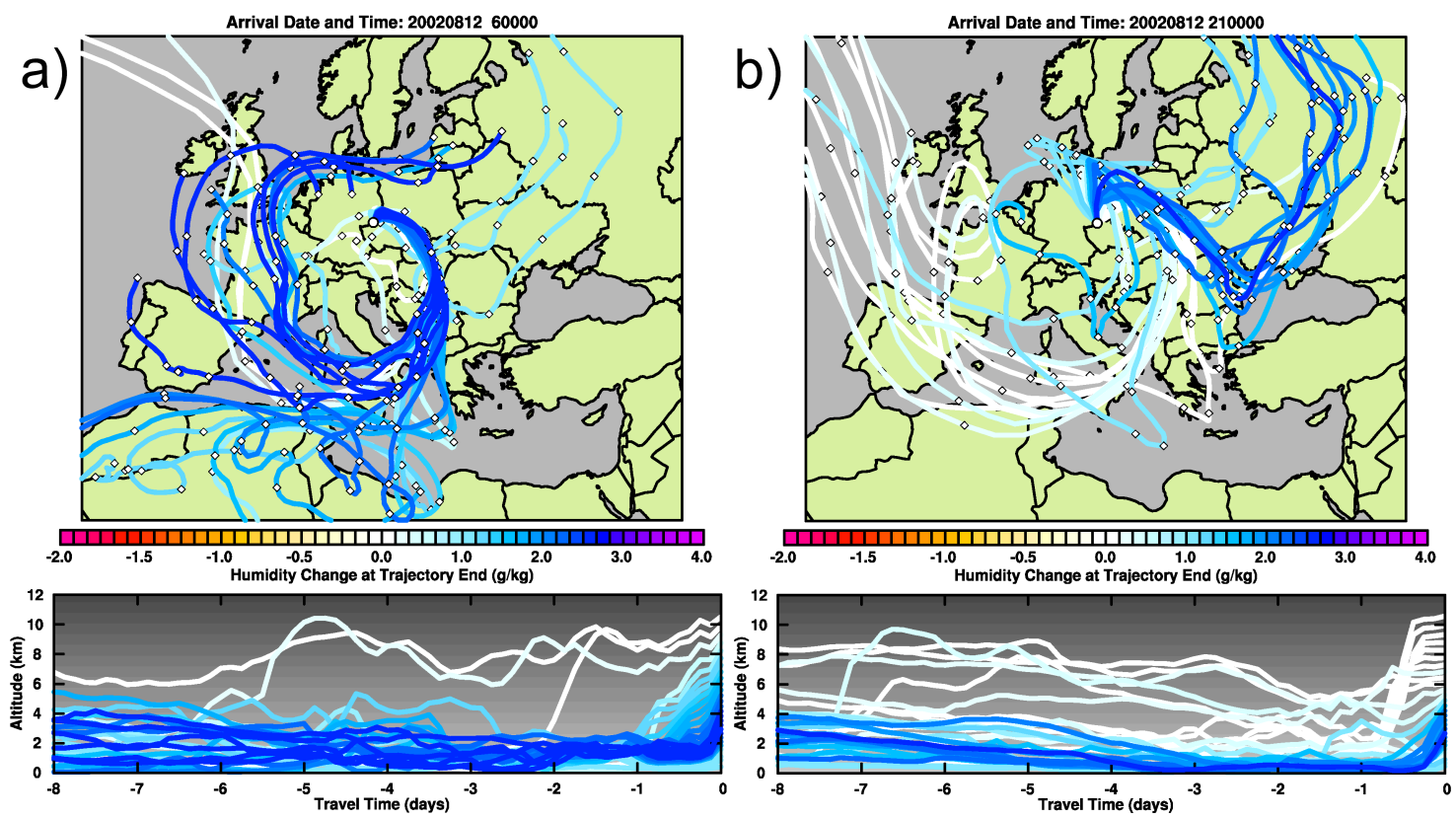

Fig. 8. 8-day backward trajectories, starting in a vertical column over Zinnwald-Georgenfeld (Saxony) at (a) 06:00 UTC and (b) 21:00 UTC on 12 August 2002. The respective trajectory colour indicates the (negative) change in specific humidity in $\mathrm{g} / \mathrm{kg}$ during the last $90 \mathrm{~min}$ before arrival at Zinnwald. Positive values represent precipitating airmasses. The upper panels show the horizontal components of the trajectory positions; a diamond is plotted on each trajectory every $24 \mathrm{~h}$. The lower panels show the respective trajectory altitudes as a function of time.
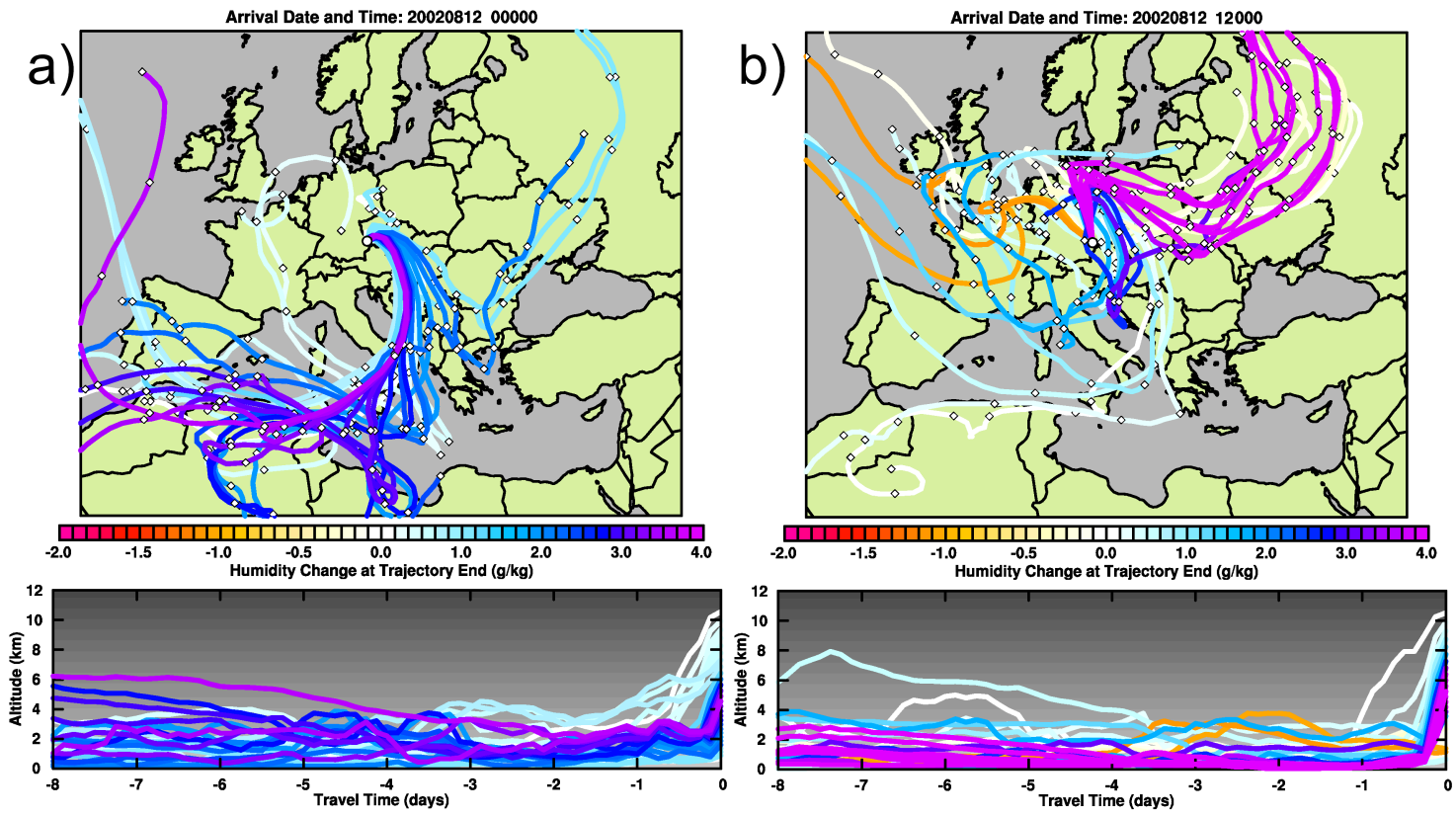

Fig. 9. As Fig. 8 but for Zwiesel (Bavaria) at (a) 00:00 UTC and (b) 12 UTC on 12 August.

in strong ascent. At 21:00 UTC, as the prolonged heavy rainfall continued with only a slow reduction in rainfall rates, the rain-bearing airmasses have come from the east, descending over Russia to traverse the northern edge of the Black Sea at low altitude, before forming a long track over land over the Ukraine and Poland, finally arriving at Zinnwald from the north. At both times, there was clearly considerable potential for picking up moisture from surface evaporation, espe- cially from the Black Sea, where SSTs were exceptionally high (Fig. 5).

Further south, at Zwiesel in eastern Bavaria (Fig. 9), where the heavy rain started and ended somewhat earlier, a similar pattern is observed: trajectories earlier in the event follow a track from the Mediterranean across eastern Europe to arrive from the east, those later in the event follow a land track from the east, in this case not actually crossing the Black Sea. 


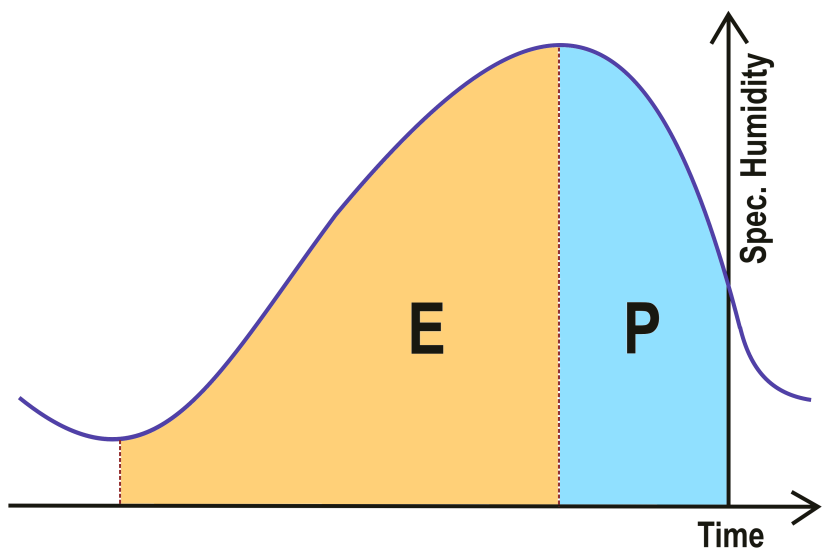

Fig. 10. Schematic specific humidity curve along a typical trajectory ending in a region of precipitation. "E" is the primary period of evaporative increase in humidity, leading up to the final period of precipitative loss of humidity, "P".

Now, in order to ensure that all possible airmass movements that were involved in the rainfall area are fully accounted for and that potential statistical errors in trajectory path calculations are reduced to a minimum, a very large number of trajectories must be calculated in time and space. For this experiment, a large set of 8-day backward 3Dtrajectories were started every $90 \mathrm{~min}$, initialised in a regular dense 3D grid over Central Europe during the main rain event, covering the $72 \mathrm{~h}$ period starting on 11 August at 00:00 UTC. Trajectories were initialised every $0.5^{\circ} \times 0.5^{\circ}$ in the horizontal within the rectangular region bounded by $45^{\circ} \mathrm{N}-54^{\circ} \mathrm{N}$ and $8^{\circ} \mathrm{E}$ to $19^{\circ} \mathrm{E}$. In the vertical, trajectories were started every $20 \mathrm{hPa}$. In total nearly 18000 trajectories were thus started every $90 \mathrm{~min}$.

Water source information can be derived from this large matrix of trajectories by examining the specific humidity field systematically along every trajectory. Specific humidity changes along all trajectories are superimposed onto a 3D base map covering a wide region where trajectories have traversed. Wherever specific humidity falls along a trajectory, the quantified value of the change can be converted directly into a precipitation amount, given that each 3D air parcel represents a certain atmospheric mass. Similarly, increases in specific humidity represent entrainment of local evaporation. In order to reduce spurious noise, only those trajectories are considered which lose a significant amount of humidity, above a certain threshold value, during the last $90 \mathrm{~min}$ before arrival at their ending point within the target matrix.

To set an optimum value for this threshold, the area-total precipitation within the target area integrated over all trajectories was estimated from humidity losses exceeding different thresholds ranging from 0.0 to $2.0 \mathrm{~g} \mathrm{~kg}^{-1}$. The total precipitation estimate remains approximately constant for thresholds up to about $0.5 \mathrm{~g} \mathrm{~kg}^{-1}$ but falls off quickly at higher thresholds. Hence, $0.5 \mathrm{~g} \mathrm{~kg}^{-1}$ (specific humidity loss over the last 90 min of each trajectory) represents the approximate amplitude of noise and is thus taken as the threshold.
This threshold results in about $10 \%$ of all trajectories being included in the calculations, which are those trajectories most directly associated with significant precipitation in the target area.

A further slightly arbitrary aspect of this method is the length of time that a backward trajectory should be calculated and its humidity changes mapped out. If the trajectory is too long, then more than one evaporation-precipitation cycle may occur along its length. Such initial evaporation would be irrelevant for the final precipitation inside the target area. To estimate a maximal length, the mean balance between total precipitation and evaporation has been calculated over all used trajectories. 8 days was found to be sufficient to account for the primary relevant evaporation-precipitation cycle. Furthermore, only the latter portion of each trajectory is included, back to the first major minimum in the specific humidity curve, at which time the primary evaporation begins. A typical humidity curve along a trajectory ending in a region of precipitation is illustrated in Fig. 10.

Thus, it is possible to estimate evaporative source regions for the rainfall. Furthermore, the trajectory method also allows an estimate of the rainfall totals themselves to be made, which can be compared for consistency and validation with ECMWF forecast and observational estimates. In Fig. 11, the total column integrated mapped evaporation and precipitation derived from the FLEXTRA experiments over successive $24 \mathrm{~h}$ periods, starting on 11 August, are shown and compared with precipitation estimates from the operational ECMWF model. Within the target area, the FLEXTRA precipitation estimates agree closely in magnitude with ECMWF values, although the former fields are slightly smoother. Outside the target area, some regions of significant net precipitation are also seen in the FLEXTRA results, in particular over parts of Croatia, Italy and the Adriatic. This can occur when air parcels have already begun to lose moisture by raining out before arrival in the target area, and then continue to do so within the target area itself. Such air parcels are likely to have started this process carrying very high specific humidity levels (note the maxima in this region in Fig. 7b).

The evaporation patterns outside the target area exhibit a similar progression to that suggested above from individual trajectories (Figs. 8 and 9). For the trajectories arriving on 11 August, evaporation maxima are concentrated over the western Mediterranean, notably the Ligurian Sea, and curiously over the Atlas mountains. On 12 August, new significant maxima have appeared over the land surface of Eastern Europe and over the northern Black Sea. By the 13 August, evaporation east of the target area has become dominant.

The suggestion that moisture was entrained over the Atlas mountains needs closer inspection. This moisture is likely to have been evaporated from the sea surface near the Algerian coast and transported inland and upwards by sub-gridscale sea-breeze circulations. The apparent water source regions over the Atlas range are thus presumably caused by back trajectories running into higher boundary layers over land than over sea. Lacking a turbulence scheme, trajectories thus 
a)

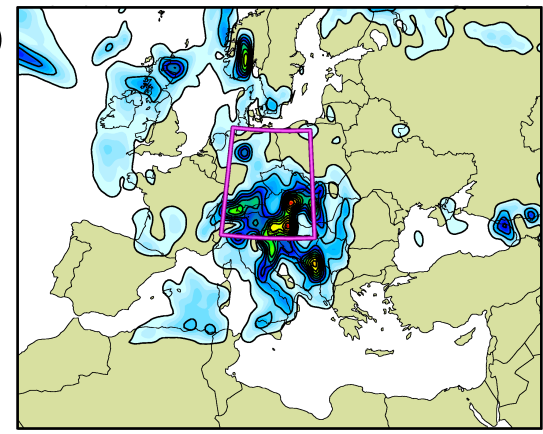

c)

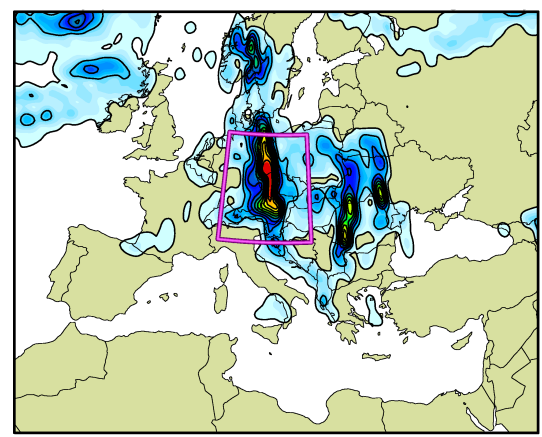

e)

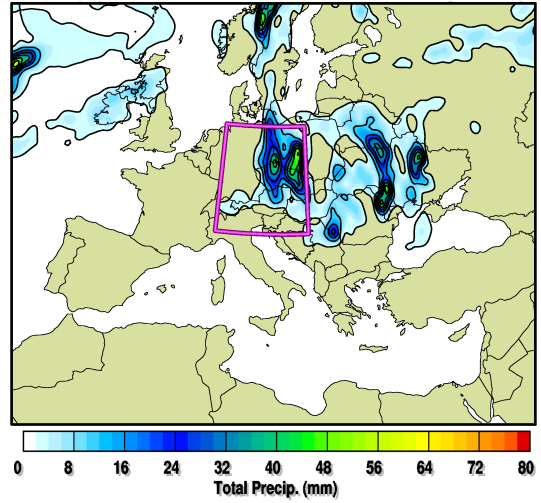

b)

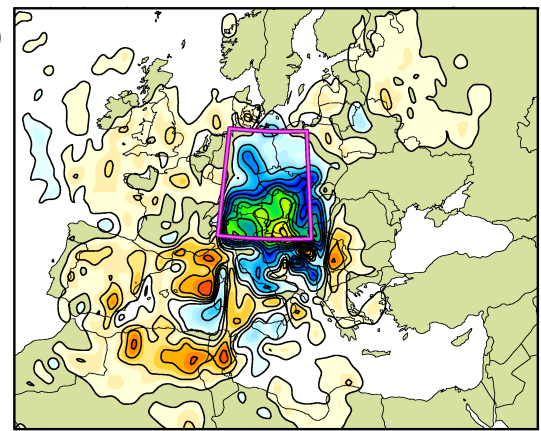

d)

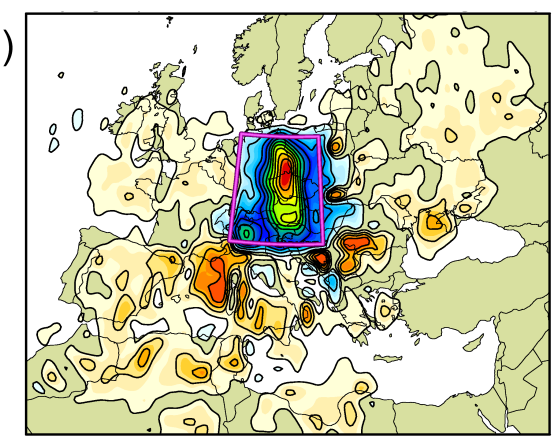

f)

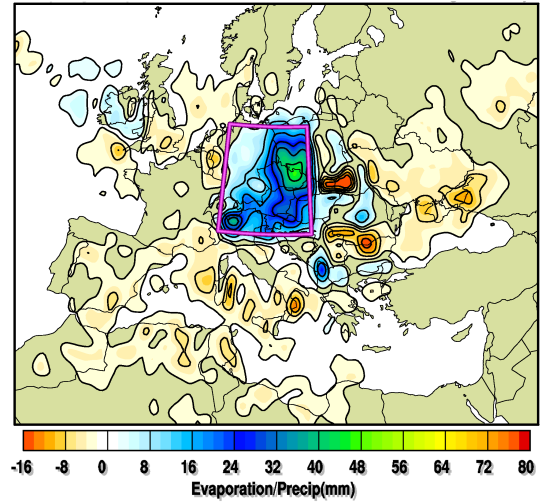

Fig. 11. $24 \mathrm{~h}$ total precipitation and total column evaporation estimates (mm) for (a), (b) 11 August, (c), (d) 12 August and (e), (f) 13 August. The right-hand column (b), (d), (f) shows the results of mapping ECMWF specific humidity changes along backward FLEXTRA trajectories starting in the target region (purple box). The left-hand column (a), (c), (e) shows comparative precipitation estimates from ECMWF operational forecasts.

might place the source region too far inland, indicative of a particular limitation of this trajectory method. Nevertheless, a more detailed investigation of the source of the moisture entrainment in this region would be necessary to confirm these speculations, but this is beyond the scope of this paper.

In Fig. 12, the total column evaporation-precipitation estimates have been split into $100 \mathrm{hPa}$ layers, summed over the whole $72 \mathrm{~h}$ period, 11-13 August, indicating where in the vertical the evaporation is being entrained and from which layers the rainfall is being generated. Below $900 \mathrm{hPa}$, evaporative entrainment is dominated by surface evaporation from water surfaces. At higher levels in the lower troposphere, the effect of land surface heating and associated sub-gridscale convection can be seen. Over Spain, Sardinia and parts of eastern Europe, maximum evaporation entrainment is occurring not at the land surface, but at the top of the boundary layer where the vertical gradient of specific humidity is large and where trajectories are likely to pass in and out of the boundary layer over a short time period. The generation of rainfall by moisture condensation and gravitational removal of subsequent raindrops occurs, as can be expected, mostly in the lower troposphere, especially between about $600 \mathrm{hPa}$ and $800 \mathrm{hPa}$.

\section{Conclusions}

The first half of August 2002 will long be remembered for the extreme precipitation events which culminated in one of the most severe floods ever experienced along sections of the river Elbe and its tributaries. Following a discussion of the synoptic meteorological situation during the primary flooding event of 11-13 August, backward trajectory mod- 
a)

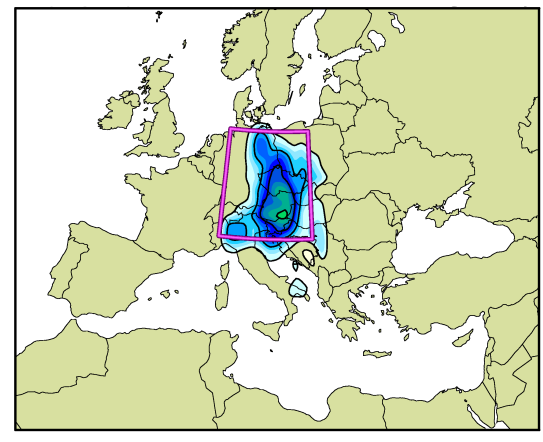

c)

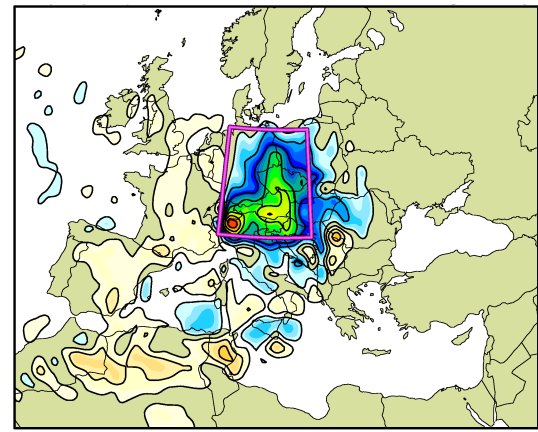

e)

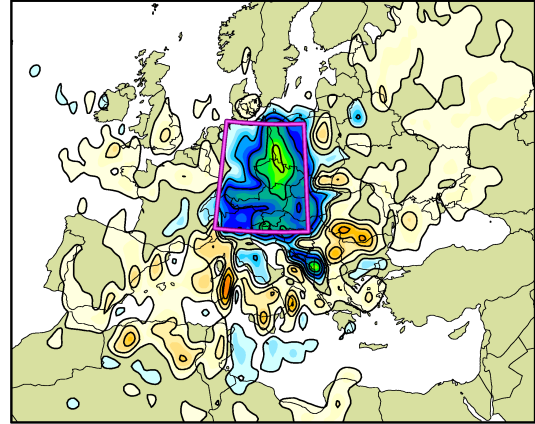

b)

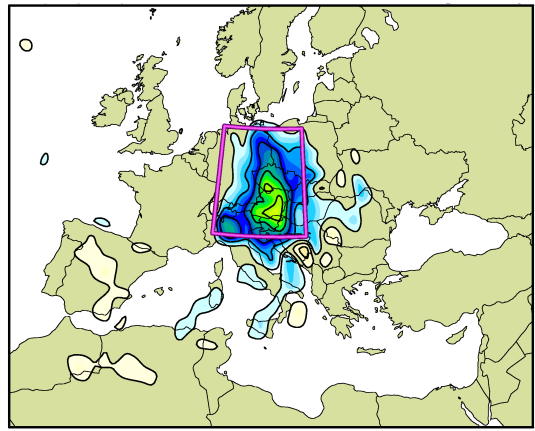

d)

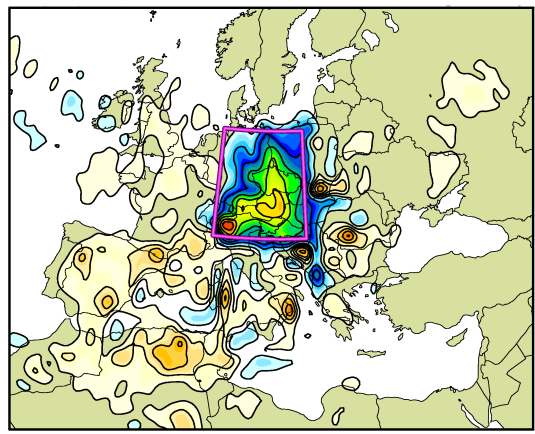

f)

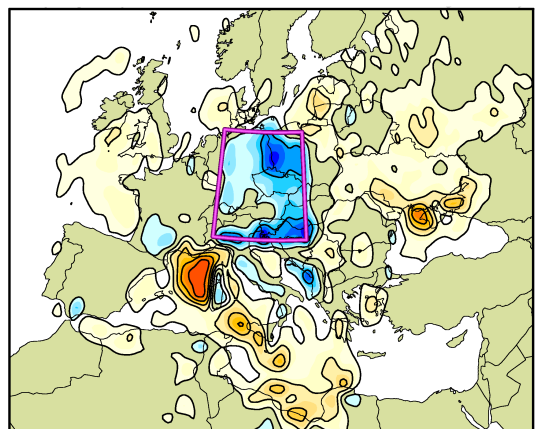

Evaporation/Precip $(\mathrm{mm})$ $\begin{array}{llllllllllllllll}-20 & -16 & -12 & -8 & -4 & 0 & 4 & 8 & 12 & 16 & 20 & 24 & 28 & 32 & 36 & 40\end{array}$

Fig. 12. $72 \mathrm{~h}$ total precipitation and evaporation estimates $(\mathrm{mm})$ for 11-13 August, split into contributions from six $100 \mathrm{hPa}$ thick layers in the vertical centred at (a) $450 \mathrm{hPa}$, (b) $550 \mathrm{hPa}$, (c) $650 \mathrm{hPa}$, (d) $750 \mathrm{hPa}$, (e) $850 \mathrm{hPa}$ and (f) $950 \mathrm{hPa}$, based on mapping ECMWF specific humidity changes along backward FLEXTRA trajectories starting in the target region (purple box).

elling of water vapour transport has been employed to determine the sources and transport pathways of the moisture which rained out. The Lagrangian trajectory model FLEXTRA was deployed in conjunction with high resolution operational meteorological analyses from the ECMWF to track a very large number of trajectories, initialized in a dense threedimensional grid array over the extreme rainfall region. By mapping out specific humidity changes along each trajectory, source-receptor relationships between evaporation and subsequent precipitation were determined for the event. The primary regions of significant surface moisture evaporation which later rained out were seen to be the northern Black Sea and parts of the Aegean and Ligurian Seas. During the early stages of the event, moisture was largely sourced from the western and central Mediterranean. This, at least, is probably quite typical for heavy rainfall events associated with a central European cyclone moving up from the central
Mediterranean. However, towards the end of this prolonged event, unusually strong evaporation from eastern European land surfaces and from the Black Sea region became dominant and certainly played an important role in enhancing the extreme nature of the event.

The method also provides a novel way of estimating precipitation totals based solely on specific humidity changes along Lagrangian airmass trajectories, while the resulting precipitation fields are closely similar to ECMWF model forecast precipitation estimates. Nevertheless, one disadvantage of this method is that it is computationally rather inefficient, since large numbers of densely-packed trajectories must be initialised at frequent time-intervals and all integrated backwards in time for several days. There is thus considerable potential for redundancy of trajectories, in particular when a single airmass trajectory is represented by several computed trajectories whose paths are almost iden- 
tical but which just end at different space-time points along the single airmass trajectory. Hence, although the method is technically correct and clearly useful for illustrating moisture transport and evaporation sources in case studies, a more efficient method of carrying it out may be desirable, especially if climatological studies are to be considered.

To this end, a parallel investigation carried out by Stohl and James (2004), who have taken the principle of trajectorydiagnostics of specific humidity changes and applied it to integrations of a Lagrangian particle dispersion model. Here, humidity changes are assessed on a very large number of domain-filling particles whose trajectories can be monitored and extended indefinitely with no redundancy. In addition to carrying out a comparable study of the August 2002 event, Stohl and James (2004) have integrated their particle dispersion model over the period of a whole year to produce global evaporation and precipitation estimates in a climatological sense, in preparation for calculating climatologies of evaporation-precipitation source-receptor relationships on global and regional scales.

Acknowledgements. This study was funded by the German Federal Ministry for Education and Research within the Atmospheric Research Programme 2000 (AFO 2000) as part of the project ATMOFAST. The ECMWF and German Weather Service are acknowledged for permitting access to ECMWF operational and re-analysis data.

Edited by: A. P. Barros

Reviewed by: D. Jacob and H. Wernli

\section{References}

Bosilovich, M. G.: On the vertical distribution of local and remote sources of water for precipitation, Meteor. Atmos. Phys., 80, 3141, 2002.

Bosilovich, M. G. and Schubert, S. D.: Water vapor tracers as diagnostics of the regional hydrologic cycle, J. Hydromet., 3, 149$165,2002$.

Bosilovich, M. G. and Sun, W.-Y.: Numerical simulation of the 1993 midwestern flood: Local and remote sources of water, J. Geophys. Res., 104, 19415-19423, 1999.

Brubaker, K. L., Dirmeyer, P. A., Sudradjat, A., Levy, B. S., and Bernal, F.: A 36-yr climatological description of the evaporative sources of warm-season precipitation in the Mississippi river basin, J. Hydromet., 2, 537-557, 2001.

Dirmeyer, P. A. and Brubaker, K. L.: Contrasting evaporative moisture sources during the drought of 1988 and the flood of 1993, J. Geophys. Res., 104, 19383-19397, 1999.

Eckhardt, S., Stohl, A., Wernli, H., James, P., Forster, C., and Spichtinger, N.: A 15-year climatology of warm conveyor belts, J. Climate, 17, 218-237, 2004.

Forster, C., Wandinger, U., Wotawa, G., James, P., Mattis, I., Althausen, D., Simmonds, P., O'Doherty, S., Kleefeld, C., Jennings, S. G., Schneider, J., Trickl, T., Kreipl, S., Jäger, H., and Stohl, A.: Transport of boreal forest fire emissions from Canada to Europe, J. Geophys. Res., 106, 22 887-22 906, 2001.

Garrett, T. J., Radke, L. F., and Hobbs, P. V.: Aerosol effects on cloud emissivity and surface longwave heating in the Arctic, J. Atmos. Sci., 59, 769-778, 2002.
Houghton, J. T., Ding, Y., Griggs, D. J., Noguer, M., van der Linden, P. J., and Xiaosu, D.: Climate Change 2001: The Scientific Basis Contribution of Working Group I to the Third Assessment Report of the Intergovernmental Panel on Climate Change (IPCC), Cambridge University Press, UK, 944, 2001.

Jackson, D. R., Driscoll, S. J., Highwood, E. J., Harries, J. E., and Russell III, J. M.: Troposphere to stratosphere transport at low latitudes as studied using HALOE observations of water vapour 1992-1997, Q. J. Roy. Meteorol. Soc., 124, 169-192, 1998.

Keil, C., Volkert, H., and Majewski, D.: The Oder flood in July 1997: Transport routes of precipitable water diagnosed with an operational forecast model, Geophys. Res. Lett., 26, 235-238, 1999.

Massacand, A. C., Wernli, H., and Davies, H. C.: Heavy precipitation on the Alpine southside: An upper level precursor, Geophys. Res. Lett., 25, 1435-1438, 1998.

Newell, R. E., Newell, N. E., Zhu, Y., and Scott, C.: Tropospheric rivers? - A pilot study, Geophys. Res. Lett., 19, 2401-2404, 1992.

Reale, O., Feudale, L., and Turato, B.: Evaporative moisture sources during a sequence of floods in the Mediterranean region, Geophys. Res. Lett., 28, 2085-2088, 2001.

Reijmer, H., van den Broeke, R., and Scheele, M. P.: Air parcel trajectories and snowfall related to five deep drilling locations in Antarctica based on the ERA-15 dataset, J. Climate, 15, 19571968, 2002.

Rudolf, B. and Rapp, J.: The century flood of the river Elbe in August 2002: Synoptic weather development and climatological aspects, Quarterly Report of the operational NWP-models of the Deutscher Wetterdienst, Special Topic July 2003, 7-22, 2003.

Saxony: Vorläufiger Kurzbericht über die meteorologischhydrologische Situation beim Hochwasser im August 2002, Sächsisches Landesamt für Umwelt und Geologie, http://www.umwelt.sachsen.de/de/wu/umwelt/lfug/ lfug-internet/documents/kb021202.pdf, 2002.

Saxony: Analyse und Prognose der meteorologischhydrologische Situation - Monatsbericht August 2003, Sächsisches Landesamt für Umwelt und Geologie, http: //www.umwelt.sachsen.de/de/wu/umwelt/lfug/lfug-internet/ documents/Monatsbericht_2003_08.pdf, 2003.

Schär, C., Lüthi, D., Beyerle, U., and Heise, E.: The soilprecipitation feedback: A process study with a regional climate model, J. Climate, 12, 722-741, 1999.

Schneider, E. K., Kirtman, B. P., and Lindzen, R. S.: Tropospheric water vapor and climate sensitivity, J. Atmos. Sci., 56, 16491658, 1999.

Stohl, A.: Computation, accuracy and applications of trajectories a review and bibliography, Atmos. Environ., 32, 947-966, 1998.

Stohl, A.: A one-year Lagrangian "climatology" of airstreams in the northern hemisphere troposphere and lowermost stratosphere, J. Geophys. Res., 106, 7263-7279, 2001.

Stohl, A. and James, P.: A Lagrangian analysis of the atmospheric branch of the global water cycle, Part 1: Method description, validation, and demonstration for the August 2002 flooding in Central Europe, J. Hydromet., 5, 656-678, 2004.

Stohl, A. and Trickl, T.: A textbook example of long-range transport: Simultaneous observation of ozone maxima of stratospheric and North American origin in the free troposphere over Europe, J. Geophys. Res., 104, 30 445-30 462, 1999.

Ulbrich, U., Brücher, T., Fink, A., Leckebusch, G., Krüger, A., and Pinto, J.: The central European floods of August 2002, Part 1 Rainfall periods and flood development, Weather, 58, 371-377, 
2003a.

Ulbrich, U., Brücher, T., Fink, A., Leckebusch, G., Krüger, A., and Pinto, J.: The central European floods of August 2002: Part 2 - Synoptic causes and considerations with respect to climatic change, Weather, 58, 434-442, 2003b.

Viterbo, P. and Betts, A. K.: Impact of the ECMWF reanalysis soil water on forecasts of the July 1993 Mississippi flood, J. Geophys. Res., 104, 19361-19366, 1999.

Wernli, H. and Davies, H. C.: A Lagrangian-based analysis of extratropical cyclones. I: The method and some applications, Q. J. Roy. Met. Soc., 123, 467-489, 1997.
Weyhenmeyer, C. E., Burns, S. J., Waber, H. N., and Macumber, P. G.: Isotope study of moisture sources, recharge areas, and groundwater flow paths within the eastern Batinah coastal plain, Sultanate of Oman, Water Resources Res., 38, 1184, doi:10.1029/2000WR000149, 2002.

Yamanaka, T., Shimada, J., and Miyaoka, K.: Footprint analysis using event-based isotope data for identifying source area of precipitated water, J. Geophys. Res., 107, 4624, doi:10.1029/2001JD001187, 2002. 